\title{
CITRA TOKOH PEREMPUAN DALAM CERITA RAKYAT JAWA TIMUR
}

\author{
Hidayah Budi Qur'ani \\ Universitas Muhammadiyah Malang \\ qurani@umm.ac.id
}

Naskah Diterima Tanggal 31 Mei 2019—Direvisi Akhir Tanggal 11 Agustus 2021—Disetujui Tanggal 20 Desember 2021 doi: https://doi.org/10.26499/jentera.v10i2.1468

\begin{abstract}
Abstrak
Penelitian ini membahas tentang bentuk-bentuk citra tokoh perempuan yang ada di dalam cerita rakyat Jawa Timur. Tokoh perempuan yang dibahas adalah tokoh utama dalam cerita. Pendekatan penelitian ini menggunakan feminisme dengan sumber data sepuluh cerita rakyat dari Jawa Timur. Teknik pengumpulan data menggunakan teknik dokumentasi. Hasil dari penelitian ini menunjukkan bahwa ada enam cerita rakyat Jawa Timur yang menggambarkan citra perempuan. Keenam cerita rakyat tersebut menggambarkan dua bentuk citra tokoh perempuan, yaitu citra fisik dan tingkah laku atau psikis. Hasil penelitian ini menunjukkan yaitu terdapat dua bentuk citra perempuan, yaitu citra diri dan citra sosial. Citra fisik dideskripsikan melalui tokoh Putri Dyah Ayu Pusparani dan Putri Kemuning. Kedua tokoh tersebut digambarkan dengan fisik yang cantik. Selanjutnya, citra psikis tokoh perempuan digambarkan di antaranya citra perempuan baik hati melalui tokoh Putri Candra Kirana, citra perempuan setia melalui tokoh Dewi Sekartaji, citra perempuan sabar melalui tokoh Rara Anteng. Adapun citra sosial perempuan digambarkan dalam hubungan perempuan dengan masyarakat, yaitu perempuan berani mengambil keputusan digambarkan melalui tokoh Ratu Ayu Kencana Wungu.
\end{abstract}

Kata-kata kunci: citra perempuan, cerita rakyat, Jawa Timur

\begin{abstract}
Oral literature is one form of literary work that has an important role in developing Indonesian literature. Folk stories are stories or literary inventions that live or have lived in a community. The story is spread, developed, or passed down orally from one generation to the younger generation. One form of the folktale is East Java folklore. This study discusses the image forms of female characters in East Java folklore. The female characters discussed are the main characters in the story. This research approach uses feminism with data sources, often folklore from East Java. Data collection techniques use documentation techniques. The results of this study are that there are two forms of female image, namely self-image and social image. The physical image is described through the characters of Putri Dyah Ayu Pusparani and Putri Kemuning. Both characters are described as physically beautiful. Furthermore, the psychic images of female characters are described including the image of a kind woman through the character of Putri Candra Kirana, the image of a loyal woman through the character of Dewi Sekartaji, the image of a patient woman through the character of Rara Anteng. The social image of women is depicted in the relationship between women and society, namely women who dare to make decisions are depicted through the figure of Ratu Ayu Kencana Wungu.
\end{abstract}

Keywords: image of women, folklore, East Java

How to Cite: Qur'ani, Hidayah Budi . (2020). Citra Tokoh Perempuan dalam Cerita Rakyat Jawa Timur. Jentera: Jurnal Kajian Sastra, 10(2), 176-187. doi: https://doi.org/10.26499/jentera.v10i2.1468 


\section{PENDAHULUAN}

Di dalam khazanah kesusastraan Indonesia terdapat dua penggolongan besar sastra, yaitu sastra lisan dan sastra tulisan. Sastra lisan maupun tulisan mempunyai peranan penting dalam perkembangan kesusastraan Indonesia. Pada hakikatnya, sastra lisan mempunyai akar yang berkaitan erat dengan sejarah bangsa Indonesia, baik aspek sosiokultural, moral, religi, hingga aspek politik (Gusnetti, Syofiani, 2018).

Dalam pemahaman budayawan, pengertian folklor memiliki makna secara keseluruhan. Pemahaman folklor adalah sebagian kebudayaan kolektif yang tersebar dan diwariskan secara turun temurun, kolektif, secara tradisional dalam versi yang berbeda, baik dalam bentuk lisan maupun contoh yang disertai dengan gerak isyarat atau alat pengingat. Folklor mempunyai ciriciri di antaranya (1) penyebaran dan pewarisannya dilakukan dengan lisan, yakni disebarkan melalui tutur kata, (2) folklor bersifat tradisional, yakni disebarkan dalam bentuk relatif tetap di antara kolektivitas mereka dalam jangka waktu yang lama minimal dua generasi, (3) folklor bersifat anonim, yaitu nama pencipta sudah tidak diketahui orang lain, (4) folklor biasanya berbentuk pola dan spontan, misalnya menggunakan kata-kata klise, (5) folklor mempunyai kegunaan dalam kehidupan bersama suatu masyarakat kolektif, misalnya tarian untuk upacara adat atau agama, (6) folklor bersifat pralogis, yaitu mempunyai logika sendiri yang tidak sesuai dengan logika umum, terutama berlaku bagi folklor lisan, dan (7) folklor menjadi milik bersama (kolektif) masyarakat adat (Danandjaja, 2002).

Cerita rakyat merupakan cerita atau cipta sastra yang hidup atau pernah hidup dalam sebuah masyarakat. Cerita itu tersebar, berkembang, atau diturunkan secara lisan dari suatu generasi ke generasi yang lebih muda. Cerita rakyat merupakan bagian dari sastra daerah, yakni sastra yang diungkapkan melalui bahasa daerah. Cerita rakyat berkembang di masa lalu ketika bahasa tulis belum dikenal. Cerita rakyat diwariskan secara lisan, penyebarannya dari mulut ke mulut sehingga sering kali ceritanya mendapatkan variasi atau tambahan bergantung pada kemahiran atau kepiawaian pawang cerita. Jadi, cerita rakyat yang sama kemungkinan besar akan diceritakan dalam versi yang berbeda meskipun inti cerita tetap sama (Rukmini, 2009).

Cerita rakyat yang kaya akan nilai-nilai moral dan kearifan lokal, bisa dijadikan sarana komunikasi untuk mengajarkan nilai-nilai pendidikan tentang kehidupan kepada masyarakat. Kebudayaan daerah di Indonesia adalah bagian yang tidak terpisahkan dari khazanah kebudayaan nasional karena kebudayaan daerah merupakan penunjang dalam pengembangan kebudayaan nasional. Hal ini merupakan suatu masalah yang tidak bisa dibiarkan begitu saja, jika tidak dibina maka akan berpengaruh kepada hilangnya nilai-nilai tradisi masyarakat (Gusnetti, Syofiani, 2018).

Cerita rakyat sebagai bagian dari karya sastra juga memiliki unsur-unsur yang jalinmenjalin sehingga mendukung secara keseluruhan cerita yang ada. Di dalam cerita rakyat juga terdapat unsur-unsur intrinsik dan ekstrinsik. Unsur-unsur intrinsik yang dibahas meliputi tema, tokoh, alur cerita/plot, latar (setting), amanat (Gusnetti, Syofiani, 2018).

Dalam perjalanannya, cerita rakyat di Indonesia dapat ditemui di seluruh provinsi. Semua provinsi di Indonesia mempunyai cerita rakyat yang beragam. Hal tersebut berhubungan dengan kultur dan budaya yang berkembang di masyarakat setempat. Selain itu, hampir semua cerita rakyat di Indonesia menceritakan dan menggambarkan tokoh perempuan dengan berbagai karakter dan kepribadian.

Penggambaran tokoh perempuan juga terdapat dalam cerita rakyat Jawa Timur. Dalam cerita rakyat Jawa Timur, tokoh perempuan digambarkan dalam dua citra, citra diri dan citra sosial. Citra diri berkaitan dengan keadaan diri perempuan yang meliputi fisik dan psikis, sedangkan citra sosial berkaitan hubungan perempuan dengan keluarga dan masyarakat.

Citra diri perempuan yang berupa citra fisik digambarkan dengan kondisi fisik tokoh perempuan, sedangkan citra psikis digambarkan dengan karakter dan tingkah laku tokoh 
perempuan. Citra fisik dapat diartikan sebagai gambaran mental individu terhadap sesuatu yang berkaitan dengan kondisi fisiknya, seperti tinggi badan, berat badan, warna kulit, serta proporsi badan (Hana Afradhila, 2014).

Citra diri perempuan yang berupa citra psikis mengacu pada tingkah laku (Sugihastuti, 2002) dapat diartikan sebagai semua wujud gambaran mental spiritual dan tingkah laku keseharian yang terekspresi oleh perempuan (Indonesia) dalam berbagai aspek, yaitu aspek fisik dan aspek psikis sebagai citra wanita, serta aspek keluarga dan masyarakat sebagai citra sosial perempuan. Citra perempuan sebagai unsur karya tercipta dalam rangka konvensi bahasa, konvensi sasatra, dan konvensi budaya. Wujud citra perempuan terbangun dari berbagai aspek, yaitu aspek fisik, psikis, keluarga, masyarakat, dan sosial.

Citra sosial perempuan yang berupa hubungan perempuan dengan keluarga dapat diartikan sebagai citra yang erat kaitannya dengan norma dan sistem yang berlaku pada masyarakat. Sistem yang berlaku tersebut berkaitan dengan tempat tinggal dan lingkungan seorang perempuan. Sistem sosial tersebut terbagi menjadi dua yaitu keluarga dan masyarakat (Sugihastuti, 2000).

Dalam cerita rakyat di Jawa Timur, terdapat penggambaran citra tokoh perempuan melalui tokoh-tokoh utamanya. Citra tersebut dapat dilihat dari citra diri dan citra sosial perempuan. Citra diri perempuan digambarkan melalui citra fisik dan citra psikis tokoh utama. Citra fisik perempuan dapat digambarkan melalui kondisi fisik tokoh perempuan dalam cerita dan citra psikis digambarkan melalui tingkah laku tokoh utama perempuan. Pada citra sosial perempuan, digambarkan melalui hubungan tokoh utama perempuan dengan keluarga dan masyarakat. Penelitian ini berfokus pada permasalahan bentuk-bentuk citra perempuan yang digambarkan oleh tokoh utama perempuan sehingga dapat ditemukan deskripsi atau penggambaran citra perempuan dalam cerita rakyat Jawa Timur.

Beberapa penelitian yang berfokus pada citra perempuan sudah pernah dilakukan sebelumnya, di antaranya penelitian yang dilakukan oleh (Kurniati, 2017) yang berjudul Citra Perempuan dalam Novel Burung Tiung Seri Gading Karya Hasan Junus. Penelitian yang dilakukan oleh Kurniati bertujuan memberikan pengetahuan kepada pembaca khususnya dan masyarakat pada umumnya tentang peran dan kedudukan perempuan dalam masyarakat yang tecermin dalam novel Burung Tiung Seri Gading serta memberikan pengetahuan kepada pembaca tentang terjadinya ketidakadilan gender dalam masyarakat yang tecermin dalam novel Burung Tiung Seri Gading. Hasil penelitian tersebut adalah adanya peran dan kedudukan perempuan di masyarakat membuat perempuan belum bisa lepas dari pekerjaan domestik serta perempuan adalah korban dari ketidakadilan gender.

Penelitian lain yang membahas tentang citra perempuan adalah penelitian dari (Sindhu, 2018) yang berjudul Images of Women in Newspaper in Kerala. Penelitian ini membahas mengenai ruang yang disediakan untuk perempuan terkait dengan berita dan penulis perempuan di surat kabar Malayalam. Penelitian tersebut menganalisis mengenai berita, fitur, editorial, wawancara, dan artikel lain yang diterbitkan di dua surat kabar Malayalam Utama, yaitu Manorama dan Mathurubhumi. Hasil dari penelitian tersebut menunjukkan bahwa surat kabar tidak memberikan peran penting terhadap isu-isu perempuan, tetapi Mathrubumi sedikit lebih baik daripada Malayala Manorama.

Penelitian lain yang juga membahas mengenai citra perempuan adalah penelitian dari (Syahrul, 2017) yang berjudul Citra Perempuan dalam Kaba Anggun Nan Tungga Karya Ambas Mahkota. Penelitian tersebut membahas mengenai citra perempuan Minangkabau sebagai anggota masyarakat dalam kaba Anggun Nan Tungga. Pendekatan yang digunakan dalam penelitian ini adalah psikologi wanita. Hasil dari penelitian tersebut menunjukkan bahwa dalam kaba Anggun Nan Tungga pada umumnya tokoh perempuan mempunyai kepribadian sangat baik karena ia memiliki kedua aspek citra perempuan, yaitu citra perempuan sebagai 
pribadi dan citra perempuan sebagai anggota masyarakat. Kedua hal tersebut sudah mencerminkan tokoh perempuan yang diidealkan.

Perbedaan penelitian ini dengan ketiga penelitian terdahulu terdapat pada objek kajian yang diteliti. Objek penelitian pertama adalan novel, kedua adalah surat kabar, dan ketiga adalah kaba, sedangkan objek dari penelitian ini adalah cerita rakyat. Fokus permasalah yang diambil sama, yaitu membahas mengenai citra perempuan. Meskipun sama-sama membahas mengenai citra perempuan, tetapi objek kajian mengenai citra perempuan mempunyai perbedaan. Jika penelitian pertama berfokus pada citra perempuan Riau, penelitian kedua berfokus pada citra perempuan di Kerala, India, dan penelitian ketiga berfokus pada citra perempuan di Minangkabau. Perbedaan fokus kajian pada citra perempuan juga akan menghasilkan temuan yang berbeda, begitu pula dengan penelitian ini yang berfokus pada citra perempuan dalam cerita rakyat di Jawa Timur. Oleh karena adanya perbedaan objek kajian dan fokus kajian tentu dapat menambah rujukan atau acuan dalam penelitian khususnya mengenai citra perempuan.

Dari uraian latar belakang di atas, penelitian yang berjudul "Citra Tokoh Perempuan dalam Cerita Rakyat Jawa Timur" penting untuk dilakukan karena memberikan gambaran dan pemahaman mengenai bentuk-bentuk citra tokoh perempuan dalam cerita rakyat yang tumbuh dan berkembang di Jawa Timur. Karakteristik dan budaya masyarakat memberikan pengaruh besar terhadap penggambaran citra tokoh perempuan. Selain itu, meneliti tentang perempuan juga tidak lepas dari feminisme. Feminisme menginginkan adanya kesetaraan antara perempuan dan laki-laki. Oleh sebab itu, dengan latar belakang budaya patriarki yang ada pada masyarakat Jawa Timur memberikan tantangan dalam penelitian ini apakah citra tokoh perempuan sudah mengarah kepada pandangan feminisme.

\section{LANDASAN TEORI}

Folklor (Endraswara, 2013) adalah sebagian kebudayaan suatu kolektif, yang tersebar dan diwariskan secara turun-temurun, di antara kolektif macam apa saja, secara tradisional dalam versi yang berbeda, baik dalam bentuk lisan maupun contoh yang disertai dengan gerak isyarat atau alat pembantu pengingat (mnemonic device).

Sastra lisan merupakan suatu teks yang berbentuk estetik dan disampaikan secara turuntemurun. Hal itu senada dengan pendapat dari (Taum, 2011) bahwa sastra lisan adalah sekelompok teks yang disebarkan dan diturun-temurunkan secara lisan, yang secara intrinsik mengandung sarana-sarana kesusastraan dan memiliki efek estetik dalam kaitannya baik dengan konteks maupun kultural dari sekelompok masyarakat tertentu. Dalam hal ini tentunya sastra lisan mempunyai ciri tertentu untuk membedakan dengan sastra-sastra yang lain. Ciri dasar sastra lisan, yaitu (1) sastra lisan bergantung kepada penutur, pendengar, ruang, dan waktu, (2) antara penutur dan pendengar terjadi konflik fisik, sarana komunikasi dilengkapi para linguistik, dan (3) bersifat anonim. Ciri-ciri tersebut di atas menegaskan bahwa sastra lisan itu dapat berkembang bergantung penuturannya sehingga kadang-kadang memunculkan adanya versi. Hal ini terjadi karena penyampaian dari penutur sampai pada pendengar kadang mempunyai persepsi yang berbeda sehingga ketika disampaikan pada pendengar berikutnya dapat ditambah maupun dikurangi. Dampak dari teks yang disampaikan secara turun-temurun dari generasi satu ke generasi berikutnya memengaruhi munculnya teks cerita yang beragam. Dalam hal ini pengarangnya anonym atau tidak diketahui identitasnya.

Dari uraian di atas dapat disimpulkan bahwa folklor atau sastra lisan merupakan sebuah cerita yang secara turun temurun disampaikan melalui mulut ke mulut. Seperti namanya yaitu sastra lisan, tidak pernah ada bentuk tulisnya sehingga cerita yang berkembang dapat diberi tambahan sesuai dengan penuturnya atau penceritanya. Oleh karena itu, sastra lisan sering kali bersifat anonim atau tidak diketahui pengarangnya. 
Cerita rakyat (Gusal, 2015) adalah cerita yang hidup dan berkembang di tengah-tengah masyarakat, dari mulut ke mulut dan pada dasarnya disampaikan oleh seseorang pada orang lain melalui penuturan lisan maupun tulisan. Isi certa rakyat pun sebenarnya bukannya tanpa unsur kebenaran dalam arti hal-hal yang dikisahkan itu berangkat dari tokoh dan peristiwa yang benar-benar ada dan terjadi. Dilihat dari segi penokohan, tokoh-tokoh dongeng pada umumnya terdiri atas dua macam, yaitu tokoh berkarakter baik dan buruk. Hal itu lumrah untuk cerita lama yang mempunyai misi untuk memberikan pelajaran moral. Selain itu, dilihat dari unsur karakter tersebut, tokoh-tokoh dongeng umumnya berkarakter sederhana.

Cerita rakyat (Toha, 2010) atau yang banyak dikenal sebagai kisah tentang peri (meskipun tidak selalu ditemukan peri di dalam ceritanya) sangat mudah dikenali. Biasanya, cerita rakyat dibuka dan ditutup dengan gaya yang khas yaitu "dulu sekali, ada seorang raja...." Dan ditutup dengan "mereka akhirnya hidup dengan bahagia". Kisah ini juga sangat singkat, dengan latar yang minim dan meletakkan kisah di tempat yang dapat diterima, serta tokoh yang hampir selalu bersifat stereotip. Misalnya gadis cantik, bapak peragu, ibu tiri yang kejam, atau nenek pengasih. Ragam cerita rakyat inilah yang paling disukai anak-anak dan masyarakat. Orang tua sangat menggemarinya. Nilai-nilai luhur di dalamnya dipercaya.

Dari uraian kedua pendapat di atas dapat disimpulkan bahwa cerita rakyat merupakan cerita yang berkembang di masyarakat pada suatu daerah. Ciri khas dari cerita rakyat adalah menceritakan dua karakter yang berlawanan yaitu baik dan buruk. Hal itu bukan tanpa sebab karena cerita rakyat selalu menghadirkan nilai-nilai karakter yang dapat dicontoh oleh masyarakat.

Citra rupa dapat diartikan sebagai gambaran yang dimiliki orang banyak mengenai pribadi, atau kesan mental (bayangan) visual yang ditimbulkan oleh sebuah kata, frasa, atau kalimat dan merupakan unsur dasar yang khas dalam karya sastra prosa dan puisi (Suharto, 2010).

Penelitian citra perempuan dapat ditujukan untuk dua kegunaan yang berbeda, yaitu untuk mengungkapkan hakikat stereotip yang menindas diubah ke dalam model-model peran serta menawarkan pandangan yang sangat terbatas dari hal-hal yang diharapkan oleh seorang perempuan. Di sisi lain, penelitian citra perempuan digunakan untuk memberikanpeluang berpikir tentang perempuan dengan membandingkan bagaimana perempuan telah direprensentasikan dan bagaimana seharusnya perempuan dipresentasikan (Sofia, 2009).

Menurut (Kamus Besar Bahasa Indonesia, 2016) citra adalah kesan mental atau bayangan visual yang ditimbulkan oleh sebuah kata, frasa, atau kalimat, dan merupakan unsur dasar yang khas dalam karya prosa dan puisi. Selanjutnya, citraan dapat diartikan sebagai cara mental pribadi atau gambaran sesuatu. Kesan atau gambaran visual yang ditimbulkan oleh sebuah kata, frasa, atau kalimat, dan merupakan unsur dasar yang khas dalam karya prosa dan puisi.

Citra (Wijiratno, 2014) adalah gambaran atau cerminan mengenai suatu hal atau objek tertentu yang diperoleh dari hasil pengindraan atau kesadaran seseorang, baik bersifat visual maupun bersifat nonvisual. Dengan demikian dapat dinyatakan pula bahwa citra berkaitan erat dengan proses mental dan proses fisik yang ada pada manusia sebagai pemberi makna dari citra itu. Seseorang dapat mengetahui citra diri seorang tokoh setelah ia mengenali keberadaan tokoh itu melalui pengindraanya terhadap tokoh tersebut. Dengan kata lain, citra tokoh itu diketahui dari proses melihat, mendengar, ataupun membaca keberadaan tokoh itu. Jadi, gambaran, cerminan, bayangan, atau citra mengenai tokoh itu diketahui dari proses pengindraan atau kesadaran yang ada pada diri seseorang. Tidak akan diketahui gambaran atau citra mengenai tokoh itu jika seseorang tidak mengetahui keberadaan fisik dan aktivitas yang dilakukan oleh tokoh tersebut.

Dari beberapa pendapat di atas, dapat diketahui bahwa citra merupakan sebuah gambaran baik itu fisik atau mental terhadap objek. Jika dikaitkan dengan perempuan, citra dapat diartikan 
sebagai gambaran fisik dan mental perempuan yang bersifat visual atau nonvisual. Seorang perempuan dapat diketahui citra dirinya ketika menampakkan atau memunculkan gambarangambaran yang dapat ditangkap oleh orang lain. Jadi, dapat dikatakan bahwa citra merupakan pantulan diri seorang perempuan melalui pengindraan.

Feminisme (Glorymarch, 2017) adalah sebuah kesadaran tentang adanya ketidakadilan bagi perempuan di seluruh dunia berupa persamaan hak antara laki-laki dan perempuan yang menjadi gerakan terorganisasi untuk mendapatkan harkat dan martabat sebagai seorang perempuan. (Rahman, 2010) menjelaskan bahwa teori feminis memusatkan perhatiannya pada tiga hal; pertama, objek utama kajiannya adalah situasi dan pengalaman wanita dalam masyarakat; kedua, membicarakan wanita sebagai subjek utama dalam proses kajiannya; dan ketiga teori ini kritis dan aktif membela wanita, berusaha menghasilkan dunia yang lebih baik untuk wanita pada khususnya dan manusia pada umumnya.

Feminisme (Tellu, S. V., \& Nurhayati, 2015) berasal dari bahasa latin "femina", yang artinya 'memiliki sifat keperempuanan'. Feminisme muncul pada tahun 1960-an, atau ada petunjuk lain bahwa feminisme telah muncul dua hingga tiga abad sebelumnya, adalah paham yang menuntut hak sepenuhnya kaum perempuan atas ketimpangan posisi dibanding laki-laki, dan lambat laun hal itu sering disebut sebagai "gerakan feminis", yang sebenarnya sudah merupakan bentuk aktualisasi upaya pembebasan diri kaum perempuan dari berbagai ketimpangan perlakuan dalam segala aspek kehidupan.

Dari pendapat di atas dapat disimpulkan bahwa feminisme merupakan sebuah gerakan yang ingin menyetarakan perempuan dan laki-laki. Feminisme berupaya agar perempuan mendapatkan posisi yang sejajar dengan laki-laki baik di ranah publik maupun domestik. Feminisme berupaya untuk membuka pandangan baru terhadap perempuan bahwa perempuan juga mempunyai kesempatan yang sama dengan laki-laki tanpa adanya perbedaan jenis kelamin.

Ruthven (1984) mengemukakan adanya ideologi seks yang bersifat patriarki dan memandang perempuan inferior terhadap laki-laki. Lebih lanjut, Ruthven (1984) mengemukakan bahwa subjek perempuan diangkat bukan karena inferioritas (natural), tetapi karena klasifikasinya secara intrinsik sebagai inferior menurut budaya yang didominasi lakilaki dan mereka (perempuan) tidak menghindar untuk hidup di dalamnya. Perempuan tidak inferior menurut sifat, tetapi diinferiorkan oleh budaya. Mereka diakulturasi (disesuaikan) ke dalam inferioritas. Dengan demikian, pembacaan terhadap teks dalam perspektif feminis berarti berusaha untuk membongkar ideologi seks yang bersifat patriarki dalam teks tersebut.

Ruthen (1984) mengemukakan bahwa kritik sastra feminis meliputi penelitian tentang bagaimana perempuan digambarkan dan bagaimana potensi perempuan di tengah kekuasaan patriarki. Dengan teori feminis, diharapkan mampu membuka pandangan-pandangan baru, terutama berkaitan dengan bagaimana karakter perempuan diwakili dalam sastra. Model analisis yang mempertanyakan keadilan sosial dari aspek hubungan antarjenis kelamin adalah analisis gender. Analisis tersebut merupakan suatu bentuk kajian yang menjadi alat kritik sastra feminis.

Menurut Ruthven (1984), salah satu bentuk kritik feminis yang berfokus pada masalah di atas adalah images of women. Kritik ini sebagai suatu jenis sosiologi. Dalam konsep ini, teksteks sastra dapat digunakan sebagai bukti untuk melihat jenis dan bentuk peran yang disediakan untuk perempuan. Tujuan yang berlawanan berkaitan dengan pemberian peran tersebut. Di satu sisi, ada keinginan untuk mengungkapkan sifat representasi strereotip yang menindas. Di sisi lain, peran tersebut memberi peluang untuk berpikir tentang perempuan dengan membandingkan bagaimana perempuan direpresentasikan dengan hal yang sebenarnya.

Dari uraian di atas dapat disimpulkan bahwa menurut pandangan Ruthven, kritik sastra feminis berfokus pada citra perempuan atau images of women. Hal ini bertujuan agar dapat 
melihat bagaimana peran-peran perempuan di dalam masyarakat patriarki. Perempuan juga harus memunculkan potensi-potensi mereka agar dapat "terlihat" di antara laki-laki. Dengan adanya teori feminis ini, dapat memberikan pandangan baru bahwa inferioritas bukanlah sebagai hal yang natural dan harus dipaksakan kepada perempuan. Akan tetapi, melalui karya sastra dapat terlihat bahwa perempuan dan laki-laki ada dua subjek yang saling berhubungan dengan seimbang.

\section{METODE PENELITIAN}

Jenis penelitian ini adalah kualitatif. Menurut Moleong (2017) penelitian kualitatif merupakan penelitian yang bermaksud memahami fenomena tentang yang dialami oleh subjek penelitian misalnya, perilaku, persepsi, motivasi, tindakan, dan lain-lain secara holistik, dan dengan cara deskripsi dalam bentuk kata-kata dan bahasa, pada suatu konteks khusus yang alamiah dan dengan memanfaatkan berbagai metode ilmiah. Penelitian kualitatif didasarkan pada upaya membangun pandangan yang diteliti secara terperinci, dibentuk dengan kata-kata, gambaran holistik, dan rumit.

Pendekatan yang digunakan dalam penelitian ini adalah feminisme yang digambarkan melalui citra tokoh perempuan dalam cerita rakyat Jawa Timur. Sumber data penelitian ini adalah sepuluh cerita rakyat dari Jawa Timur yang berjudul Ande-Ande Lumut, Legenda Gunung Kelud, Jaka Seger dan Rara Anteng, Jaka Budug dan Putri Kemuning, serta Damarwulan dan Minakjingga. Sumber data tersebut diambil dari cerita rakyat yang diterbitkan oleh Balai Kajian dan Pengembangan Budaya Melayu dan dimuat di website (Cerita Rakyat Nusantara, 2009). Data penelitian ini berupa frasa, kata, dan kalimat yang menggambarkan mengenai bentuk-bentuk citra tokoh perempuan dalam cerita rakyat Jawa Timur.

Teknik pengumpulan data dalam penelitian ini menggunakan metode dokumentasi, yaitu mencari data mengenai hal-hal atau variabel yang berupa catatan, transkip, buku, dan dokumen lain yang relevan dengan penelitian. Teknik analisis data dalam penelitian ini dilakukan secara berkesinambungan dari awal sampai akhir dengan menggunakan teknik interaktif seperti yang dikemukan oleh Miles dan Huberman yaitu (1) reduksi data, yaitu membuat abstraksi seluruh data yang diperoleh dari seluruh catatan lapangan hasil observasi wawancara dan pengkajian dokumen. Reduksi data merupakan suatu bentuk analisis data yang menajamkan, mengharapkan hal-hal penting, menggolongkan, mengarahkan, membuang yang tidak dibutuhkan, dan mengorganisasikan data agar sistematis, serta dapat membuat satu simpulan yang bermakna. (2) Penyajian data, yaitu sekumpulan informasi tersusun yang memberi kemungkinan adanya penarikan kesimpulan dalam pengambilan tindakan. Proses penyajian data ini mengungkapkan secara keseluruhan dari sekelompok data yang diperoleh agar mudah dibaca dan dipahami, yang paling sering digunakan untuk penyajian data dalam penelitian kualitatif adalah dengan teks yang bersifat naratif. (3) Kesimpulan dan verifikasi, yaitu data yang sudah diatur sedemikian rupa (dipolakan, difokuskan, disusun secara sistematis) kemudian disimpulkan sehingga makna data dapat ditemukan. Akan tetapi, kesimpulan tersebut hanya bersifat sementara dan umum.

\section{PEMBAHASAN}

Pada bagian pembahasan dijelaskan bentuk-bentuk citra perempuan yang terdapat dalam cerita rakyat Jawa Timur. Ada dua bentuk citra perempuan dalam cerita Rakyat di Jawa Timur, yaitu citra diri dan citra sosial perempuan. Pembagian tersebut berdasarkan pada penggambaran citra diri tokoh utama perempuan melalui fisik dan psikis, serta penggambaran hubungan tokoh utama perempuan dengan keluarga dan masyarakat. Pada subbab di bawah ini diuraikan bentuk-bentuk kedua citra tokoh tersebut. 


\section{Citra Diri Perempuan}

Citra diri perempuan dapat diartikan sebagai gambaran dari keadaan fisik yang digambarkan melalui deskripsi dalam sebuah cerita. Dalam cerita rakyat Jawa Timur, citra fisik tokoh utama perempuan digambarkan melalui dua tokoh, yaitu Putri Dyah Ayu Pusparani dalam cerita Legenda Gunung Kelud dan Putri Kemuning dalam cerita Jaka Budug dan Putri Kemuning. Citra fisik kedua tokoh perempuan tersebut diuraikan sebagai berikut.

\section{Citra Fisik Tokoh Perempuan}

Citra fisik diartikan sebagai gambaran fisik perempuan yang dapat dilihat dengan mata kepala. Citra fisik perempuan dapat digambarkan sebagai sosok perempuan yang sudah dewasa dan mempunyai pertumbuhan fisik yang berbeda dengan laki-laki, menyusui, dan melahirkan (Sugihastuti, 2000). Dalam cerita rakyat Jawa Timur, citra fisik tokoh perempuan digambarkan dengan narasi yang menunjukkan bahwa perempuan mempunyai gambaran fisik yang cantik.

Citra perempuan cantik digambarkan oleh tokoh Putri Dyah Ayu Pusparani dalam cerita rakyat Legenda Gunung Kelud. Dalam cerita rakyat Legenda Gunung Kelud dikisahkan bahwa Prabu Brawijaya mempunyai putri bernama Putri Dyah Ayu Pusparani yang digambarkan sebagai perempuan cantik dengan memiliki keindahan tubuh yang sangat memesona, kulitnya lembut bagai sutra, dan wajahnya elok berseri bagaikan bulan purnama. Kecantikan Putri Dyah Ayu Pusparini yang memesona membuat para lelaki ingin menjadikannya istri. Akan tetapi, Putri Dyah Ayu tidak mau sembarangan memilih calon suami sehingga ayahnya mengadakan sayembara untuk memilihkan calon suami bagi anaknya.

Selain itu, penggambaran secara fisik juga digambarkan melalui tokoh Putri Kemuning. Putri Kemuning merupakan anak dari Prabu Aryo Seto yang bertahta di kerajaan Ringin Anom di Ngawi. Putri Kemuning digambarkan sebagai sosok perempuan yang rupawan dan sesuai namanya, tubuh sang putri sangat harum bagaikan bunga kemuning.

Dari uraian deskripsi di atas, dapat dilihat bahwa Putri Dyah Ayu Pusparani dan Putri Kemuning mempunyai fisik yang sempurna. Hal itu terlihat dalam narasi cerita yang menyatakan kecantikan Putri Dyah Ayu Pusparani dan Putri Kemuning melalui kalimat "kulitnya lembut bagai sutra", "wajahnya elok berseri bagaikan bulan purnama", dan "sosok perempuan yang rupawan dan sesuai namanya, tubuh sang putri sangat harum bagaikan bunga kemuning". Penggambaran tokoh perempuan secara fisik dalam cerita rakyat Jawa Timur sesuai dengan pendapat (Hana Afradhila, 2014) yang mengemukakan bahwa citra fisik digambarkan dengan kondisi fisik tokoh perempuan, sedangkan citra psikis digambarkan dengan karakter dan tingkah laku tokoh perempuan.

\section{Citra Psikis Tokoh Perempuan}

Citra Psikis dapat diartikan bahwa perempuan dapat direpresentasikan melalui aspek psikisnya. Hal tersebut disebabkan karena seorang perempuan adalah individu yang mempunyai perasaan, pemikiran, dan keinginan. Oleh karena itu, citra psikis ini perempuan dapat digambarkan melalui kekuatan emosionalnya melalui sebuah cerita (Nugroho, 2020). Citra psikis perempuan dalam cerita rakyat Jawa Timur digambarkan melalui tokoh Putri Candra Kirana dalam cerita Keong Mas, Dewi Sekartaji dalam cerita Ande-Ande Lumut, Rara Anteng dalam cerita Jaka Seger dan Rara Anteng.

\section{Citra Perempuan Baik}

Citra perempuan baik digambarkan melalui tokoh Putri Candra Kirana dalam cerita rakyat Keong Mas. Kebaikan hati tokoh Putri Candra Kirana dapat digambarkan ketika ia 
menjadi seekor keong mas dan diselamatkan oleh Mbok Rini, Putri Candra Kirana membalas kebaikannya dengan memasakkan Mbok Rini makanan kesukaannya. Hal itu digambarkan ketika Mbok Rondo pergi bekerja mencari ikan, lantas keong mas tersebut berubah menjelma menjadi seorang putri yang cantik dan segera memasak makanan untuk Mbok Rini.

Kebaikan Putri Candra Kirana tidak selesai sampai di situ. Ketika dirinya sudah kembali menjadi manusia, ia juga membawa serta Mbok Rini menuju istana. Ia membalas budi pada mbok Rini dengan menjadikan mbok Rini sebagai bagian dari keluarga kerajaan. Penggambaran tokoh Putri Candra Kirana sesuai dengan pendapat (Suharto, 2010) Citra rupa dapat diartikan sebagai gambaran yang dimiliki orang banyak mengenai pribadi, atau kesan mental (bayangan) visual yang ditimbulkan oleh sebuah kata, frasa, atau kalimat dan merupakan unsur dasar yang khas dalam karya sastra prosa dan puisi.

Melalui penggambaran pribadi tokoh Putri Candra Kirana, dapat diketahui bahwa sosok Putri Candra Kirana memiliki penggambaran pribadi yang baik. Karakter Putri Candra Kirana yang mempunyai kuasa untuk membawa Mbok Rini (kalangan biasa) menjadi salah satu bagian dari keluarga kerajaan selaras dengan pendapat Ruthven (1984) bahwa di tengah-tengah kekuasaan patriarki, perempuan dapat membuat keputusan sendiri.

\section{Citra Perempuan Setia}

Ande-Ande lumut merupakan salah satu cerita rakyat yang berkembang di daerah Kediri. Cerita Rakyat Ande-Ande Lumut mengisahkan seorang raja yang bernama Panji Asmara Bangun menyamar menjadi laki-laki biasa bernama Ande-Ande Lumut untuk mencari istrinya yang menghilang dari kerajaan bernama Dewi Sekar Taji. Ande-Ande Lumut mengadakan sayembara untuk mencari istri dan berharap Dewi Sekartaji mengikuti sayembara tersebut.

Singkat cerita berita sayembara tersebut sampai di telinga Dewi Sekartaji. Dewi Sekartaji ingin mengikuti sayembara tersebut karena dirinya meyakini bahwa yang membuat sayembara adalah suaminya. Dalam perjalanan menuju tempat sayembara, tepatnya di pinggiran Sungai Bengawan Solo, Dewi Sekartaji yang berubah nama menjadi Klenting Kuning dihadang oleh seekor yuyu kangkang. Yuyu kakang tersebut mengatakan jika ingin mendapatkan bantuan untuk menyeberangi sungai, Klenting Kuning harus menciumnya. Klenting Kuning menolak permintaan yuyu kangkang karena ia tidak ingin mengkhianati suaminya dengan mencium laki-laki lain.

Dari gambaran sikap Dewi Sekartaji, dapat diketahui bahwa Dewi Sekartaji memiliki citra perempuan setia. Hal tersebut dibuktikan dengan tingkah laku Dewi Sekartaji yang tidak mau mencium yuyu kangkang karena tidak ingin mengkhianati suaminya. Penggambaran citra setia tersebut sesuai dengan pendapat (Wijiratno, 2014) yang menyatakan bahwa citra merupakan gambaran atau cerminan mengenai suatu hal atau objek tertentu yang diperoleh dari hasil pengindraan atau kesadaran seseorang, baik bersifat visual maupun bersifat nonvisual. Oleh karena itu, meskipun tidak digambarkan secara visual, tetapi dengan penggambaran tingkah laku Dewi Sekartaji tersebut dapat diketahui bahwa ia merupakan sosok perempuan yang setia.

Citra perempuan setia juga digambarkan melalui tokoh Rara Anteng. Rara Anteng menolak semua pinangan tersebut karena ia telah menjalin hubungan dengan seorang lelaki bernama Jaka Seger. Sikap Rara Anteng menunjukkan bahwa ia mampu menentukan nasibnya sendiri. Hal itu sesuai dengan pandangan feminisme (Tellu, S. V., \& Nurhayati, 2015) yang merupakan paham yang menuntut hak sepenuhnya kaum perempuan atas ketimpangan posisi dibanding laki-laki, dan lambat laun hal itu sering disebut sebagai "gerakan feminis", yang sebenarnya sudah merupakan bentuk aktualisasi upaya pembebasan diri kaum perempuan dari berbagai ketimpangan perlakuan dalam segala aspek kehidupan. 


\section{Citra Perempuan Sabar}

Dalam cerita rakyat di Jawa Timur, terdapat cerita yang menggambarkan perempuan dengan sikap sabar. Cerita tersebut berjudul Jaka Seger dan Rara Anteng. Jaka Seger dan Rara Anteng merupakan cerita rakyat yang berkembang di Kabupaten Probolinggo. Rara Anteng merupakan anak dari Raja Majapahit yang meninggalkan kerajaannya dan menetap di lereng Gunung Bromo. Rara Anteng merupakan perempuan yang cantik dan kecantikannya pun tersebar di penjuru daerah. Kecantikan Rara Anteng menarik sosok raksasa yang tinggal di sekitar lereng gunung Bromo dan ingin meminang dirinya.

Rara Anteng yang tidak mau dinikahi oleh raksasa tersebut, berupaya untuk mencari alasan agar tidak jadi diperistri oleh raksasa tersebut. Rara Anteng digambarkan memilih sikap tenang dan sabar dalam menghadapi raksasa yang kuat dan kejam. Rara Anteng memasang siasat untuk menolak pinangan raksasa tersebut. Meskipun merasa gugup, Rara Anteng berusaha tenang dan sabar agar siasat yang direncanakan berjalan lancar.

Kesabaran tokoh Rara Anteng juga ditunjukkan ketika ia belum dikaruniai anak. Banyak cara yang sudah dilakukan keduanya untuk mendapatkan keturunan tetapi Tuhan belum memberikan kepercayaan kepada mereka. Ketika suaminya, Jaka Seger sudah putus asa dan menyerah dengan keadaan justru Rara Anteng dengan sabar meyakinkan suaminya bahwa Tuhan belum memberikan rezeki dan kepercayaan kepada mereka. Kesabaran Rara Anteng membuahkan hasil, ia mengandung dan melahirkan anak sebanyak dua puluh lima.

Penggambaran tokoh Rara Anteng sesuai dengan pendapat Sofia (2009) yang mengemukakan bahwa citra perempuan dapat ditujukan untuk dua kegunaan yang berbeda, yaitu untuk mengungkapkan hakikat stereotip yang menindas diubah ke dalam model-model peran serta menawarkan pandangan yang sangat terbatas dari hal-hal yang diharapkan oleh seorang perempuan. Di sisi lain, penelitian citra perempuan digunakan untuk memberikan peluang berpikir tentang perempuan dengan membandingkan bagaimana perempuan telah direprensentasikan dan bagaimana seharusnya perempuan dipresentasikan.

Penggambaran citra tokoh perempuan melalui Rara Anteng dapat diketahui bahwa perempuan juga mempunyai sikap sabar. Sikap sabar dalam hal ini bukan karena takut melainkan upaya agar dapat menguasai keadaan dan dapat menentukan keputusan yang benar. Sikap sabar merupakan upaya agar perempuan tidak tergesa-gesa dalam melakukan suatu tindakan dan menjerumusakan ke dalam permasalahan. Hal tersebut sesuai dengan asumsi dari feminis bahwa perempuan harus menghargai diri sendiri dan berani membuat keputusan agar tidak dipandang sebelah mata oleh laki-laki.

\section{Citra Sosial Perempuan}

Citra sosial dapat diartikan bagaimana perempuan dalam kehidupannya, yaitu berperan dalam keluarga dan masyarakat. Dalam keluarga, perempuan dapat berperan sebagai anak, ibu, kakak, adik, dan istri. Dalam kehidupan masyarakat, menunjukkan perempuan tidak bisa hidup sendiri dan memerlukan orang lain (Nugroho, 2020). Dalam cerita rakyat Jawa Timur, citra sosial perempuan digambarkan dalam tokoh Retna Ayu Kencana Wungu dalam cerita Damarwulan dan Minakjinggo. Citra sosial digambarkan dalam bentuk hubungan tokoh perempuan dengan masyarakat. Hal itu digambarkan oleh tokoh Retna Ayu Kencana Wungu yang berani mengambil keputusan.

Citra perempuan berani mengambil keputusan yang digambarkan dalam cerita rakyat Jawa Timur yaitu pada tokoh Retna Ayu Kencana Wungu. Tokoh Retna Ayu Kencana Wungu terdapat dalam cerita Damarwulan dan Minakjingga. Damarwulan dan Minakjingga merupakan cerita yang berkembang di daerah Banyuwangi. Cerita ini mengisahkan seorang seorang ratu bernama Retna Ayu Kencana Wungu yang menguasai kerajaan Majapahit yang ke-6. 
Retna Ayu Kencana Wungu merupakan ratu yang dapat menaklukkan kerajaan-kerajaan kecil sampai dengan kerajaan di Trowulan. Salah satu kerajaan yang tidak dapat ditaklukkan adalah kerajaan Blambangan. Oleh karena itu, Retna Ayu Kencana Wungu membuat sayembara yang berisi siapa saja yang dapat mengalahkan raja Blambangan maka akan dijadikan suami dan raja. Selain menjadi pemimpin, sosok Retna Ayu Kencana Wungu juga digambarkan sebagai seorang perempuan yang tegas. Sikap tegasnya digambarkan ketika ia mendapatkan laporan antara Damarwulan, Layang Seta, dan Layang Kumitr yang mengaku telah mengalahkan Minakjingga. Retna Ayu Kencana Wungu mengambil sikap untuk mengadakan pertarungan antara ketiganya untuk menentukan siapa yang berkata benar.

Dari penggambaran tokoh Retna Ayu Kencana Wungu dapat disimpulkan bahwa perempuan juga mempunyai kesempatan untuk menjadi pemimpin, mampu menentukan sikap, dan mampu mengambil keputusan. Melalui citra psikis atau tingkah laku, Tokoh Retna Ayu Kencana Wungu dapat mengambil sikap dalam menyelesaikan permasalahan yang ada di dalam hidupnya. Sikap Retna Ayu Kencana Wungu sesuai dengan cita-cita feminis yang menginginkan persamaan hak antara perempuan dan laki-laki.

Citra tokoh Retna Ayu Kencana Wungu yang mampu sejajar dengan laki-laki sesuai dengan pendapat yang dikemukakan oleh Ruthen (Ruthven, 1984) bahwa kritik sastra feminis meliputi penelitian tentang bagaimana perempuan digambarkan dan bagaimana potensi perempuan di tengah kekuasaan patriarki. Dengan teori feminis, diharapkan mampu membuka pandangan-pandangan baru, terutama berkaitan dengan bagaimana karakter perempuan diwakili dalam sastra. Model analisis yang mempertanyakan keadilan sosial dari aspek hubungan antarjenis kelamin adalah analisis gender. Analisis tersebut merupakan suatu bentuk kajian yang menjadi alat kritik sastra feminis.

\section{SIMPULAN}

Citra tokoh perempuan dalam cerita rakyat Jawa Timur digambarkan dalam cerita Keong Mas, Ande-Ande Lumut, Legenda Gunung Kelud, Jaka Seger dan Rara Anteng, Jaka Budug dan Putri Kemuning, dan Damarwulan dan minakjingga. Citra tokoh perempuan dalam enam cerita rakyat tersebut digambarkan dalam dua bentuk yaitu citra diri perempuan dan citra sosial perempuan.

Citra diri perempuan digambarkan dalam bentuk fisik dan psikis. Citra fisik dideskripsikan melalui tokoh Putri Dyah Ayu Pusparani dan Putri Kemuning. Kedua tokoh tersebut digambarkan dengan fisik yang cantik. Selanjutnya, citra psikis tokoh perempuan digambarkan diantaranya citra perempuan baik hati melalui tokoh Putri Candra Kirana, citra perempuan setia melalui tokoh Dewi Sekartaji, citra perempuan sabar melalui tokoh Rara Anteng. Adapun citra sosial perempuan digambarkan dalam hubungan perempuan dengan masyarakat yaitu perempuan berani mengambil keputusan digambarkan melalui tokoh Ratu Ayu Kencana Wungu.

Bentuk-bentuk citra perempuan menggambarkan bagaimana kedudukan perempuan dalam cerita rakyat Jawa Timur. Perempuan dalam cerita Rakyat Jawa Timur digambarkan memiliki tingkah laku yang setara dengan laki-laki. Perempuan dalam cerita rakyat di Jawa Timur mempunyai tindakan yang mampu menentukan jalan hidupnya sendiri tanpa takut terhadap dominasi laki-laki. Penggambaran citra tokoh utama perempuan dalam cerita tidak selalu berfokus pada citra fisik saja, tetapi juga melalui tingkah laku. Oleh karena itu, dengan penggambaran citra tingkah laku tokoh perempuan utama dapat diketahui bahwa citra perempuan dalam cerita rakyat Jawa Timur sesuai dengan cita-cita feminisme yaitu menyetarakan diri dengan laki-laki. 
Hidayah Budi Qur'ani

\section{DAFTAR PUSTAKA}

Cerita Rakyat Nusantara. (2009). Balai Kajian dan Pengembangan Budaya Melayu. http://ceritarakyatnusantara.com/id/browse/432-Jawa-Timur

Danandjaja, J. (2002). Folklore Indonesia, Ilmu Gosip, Dongeng, dan Lain lain. Pustaka Utama Grafiti.

Endraswara, S. (2013). Folklor Nusantara. Ombak.

Glorymarch, R. R. (2017). Posisi Perempuan Dalam Prostitusi Lesbi Pada Novel Perempuan Karya Maman Suherman dalam Perspektif Feminisme. 05.

Gusal, L. O. (2015). Nilai-Nilai Pendidikan dalam Cerita Rakyat Sulawesi Tenggara Karya La Ode Sidu. Humanika, 5(15).

Gusnetti, Syofiani, dan R. I. (2018). Struktur dan Nilai-Nilai Pendidikan Dalam Cerita Rakyat Kabupaten Tanah Datar Provinsi Sumatera Barat. Gramatika STKIP PGRI Sumatera Barat, 1(2), 183-192. https://doi.org/10.22202/jg.2015.v1i2.1238

Hana Afradhila, Y. I. (2014). Hubungan Antara Fanatisme Terhadap Produk Perawatan Wajah dengan Citra Diri Fisik Pada Wanita Dewasa Awal. Empati, 3(4), 224-234. https://ejournal3.undip.ac.id/index.php/empati/article/view/7576

Kamus Besar Bahasa Indonesia. (2016). Badan Pengembangan dan Pembinaan Bahasa, Kementrian Pendidikan dan Kebudayaan Republik Indonesia.

Kurniati, C. P. (2017). Citra Perempuan dalam Novel Burung Tiung Seri Gading Karya Hasan Junus. Madah: Jurnal Bahasa dan Sastra, 5(2), 157-170. http://ejurnalbalaibahasa.id/index.php/madah/article/view/503

Moleong, L. J. (2017). Metodologi Penelitian Kualitatif (Edisi Revisi). In PT. Remaja Rosda Karya.

Nugroho, D. I. W. (2020). Citra Perempuan dalam Novel Hati Suhita Karya Khilma Anis dan Implikasinya Terhadap Pembelajaran Bahasa Indonesia di SMA (Issue januari). Universitas Panca Tegal.

Rahman, M. T. (2010). Social Justice in Western and Islamic Thought: A Comparative Study of John Rawl's and Sayyid Qutb's Theories of Social Justice. Jabatan Akidah dan Pemikiran Islam, Akademi Pengajian Isla.

Rukmini, D. (2009). Cerita Rakyat Kabupaten Sragen (Suatu Kajian Struktural dan Nilai Edukatif) [Universitas Sebelas Maret Surakarta]. In Universitas Sebelas Maret Surakarta. https://doi.org/10.1038/132817a0

Ruthven. (1984). Feminist Literary Studies: an Introduction. Cambridge University Press.

Sindhu, S. (2018). Images of Women in Newspapers in Kerala. Research Journal of Humanities and Social Sciences, 9(1), 125-130. http:/www.indianjournals.com/ijor.aspx?target=ijor:rjhss\&volume $=9 \&$ issue $=1 \&$ article $=022$

Sofia, A. (2009). Aplikasi Kritik Sastra Feminis: Perempuan dalam Karya-Karya Kuntowijoyo. Citra Pustaka.

Sugihastuti. (2000). Wanita di Mata Wanita: Perspektif Sajak-Sajak Toeti Heraty. Nuansa.

Sugihastuti, S. (2002). Kritik Sastra Feminis: Teori dan Aplikasinya. Pustaka Pelajar.

Suharto, S. (2010). Kritik Sastra Feminis, Teori dan Aplikasinya. Pustaka Pelajar.

Syahrul, N. (2017). Citra Perempuan dalam Kaba Anggun Nan Tungga Karya Ambas Mahkota. Jentara: Jurnal Kajian Sastra, 2(2).

Taum, Y. Y. (2011). Studi Sastra Lisan: Sejarah, Teori, Metode dan Pendekatan Disertai Contoh Penerapannya. Lamalera.

Tellu, S. V., \& Nurhayati, M. S. (2015). Persoalan Feminisme dalam Cerpen “Beri Aku Waktu” Karya Evi Idawati. Sintesi, 9(2), 76-82. http://e-journal.usd.ac.id/index.php/sintesis/article/view/915

Toha, S.-R. K. (2010). Pedoman Penelitian Sastra Anak: Edisi Revisi. Yayasan Pustaka Obor.

Wijiratno. (2014). Citra Perempuan. Media Karya. 